\title{
Pengaruh Lama Perendaman Air Kelapa dan Frekuensi Penyemprotan Urin Sapi Terhadap Pertumbuhan Bibit Pinang (Areca catechu, L.)
}

\author{
Kristina Igniosa Nainahas ${ }^{\text {a }}$ dan Roberto I. C. O. Taolin ${ }^{\mathrm{b}}$ \\ ${ }^{a}$ Fakultas Pertanian, Universitas Timor, Kefamenanu, TTU - NTT, Indonesia. \\ ${ }^{b}$ Fakultas Pertanian, Universitas Timor, Kefamenanu, TTU - NTT, Indonesia.
}

\section{Article Info}

Article history:

Received 18 Oktober 2016

Received in revised form 21 November 2016

Accepted 7 Januari 2017

Keywords:

Lama Perendaman

Air Kelapa

Urin Sap

Pinang

Areca catechu, L

\section{Abstrak}

Penelitian ini bertujuan untuk mengetahui pengaruh lama perendaman air kelapa dan frekuensi penyemprotan urin sapi terhadap pertumbuhan bibit pinang serta mengetahui pengaruh lama perendaman air kelapa dan frekuensi penyemprotan urin sapi yang tepat untuk pertumbuhan bibit pinang yang optimum. Percobaan lapangan menggunakan Rancangan Acak Kelompok (RAK) faktorial. Faktor pertama adalah pengaruh lama perendaman air kelapa yang terdiri dari empat aras yaitu tanpa perendaman, 3 jam, 6 jam dan 9 jam. Faktor kedua adalah frekuensi penyemprotan urin sapi yang terdiri dari empat aras yaitu tanpa penyemprotan, satu kali, dua kali dan tiga kali. Hasil penelitian menunjukan tidak terjadi pengaruh interaksi antara lama perendaman dan frekuensi penyemprotan pada semua parameter. Lama perendaman dalam air kelapa tidak berpengaruh nyata pada semua parameter sedangkan frekuensi penyemprotan urin sapi juga hanya berpengaruh nyata terhadap tinggi tanaman 30 HST. Perendaman dalam air kelapa selama enam jam lebih baik bagi pertumbuhan bibit pinang, sedangkan penyemprotan urin sapi memberikan dampak negatif terhadap pertumbuhan bibit pinang. @2017 dipublikasikan oleh Savana Cendana.

\section{Pendahuluan}

Areca catehcu, L. merupakan salah satu tanaman tahunan yang sangat dikenal oleh masyarakat karena secara alami penyebarannya cukup luas di berbagai daerah. Pinang memiliki banyak manfaat, namun, saat ini banyak masyarakat hanya mengenal pinang sebagai tanaman yang bermanfaat untuk bahan makan sirih saja, padahal masih banyak manfaat lain antara lain sebagai tanaman penghijau, bahan bagunan, bahan ramuan tradisional, bahan baku industri kosmetik, kesehatan dan bahan pewarna pada industri tekstil (Lutony, 1992).

Seiring dengan meningkatnya pemanfaatan pinang, permintaan untuk ekspor juga terus meningkat. Negara tujuan ekspor saat ini meliputi Pakistan, Nepal, Banglades, India, Singapura dan Thailand. Indonesia menjadi produsen utama pinang dunia dengan produksi yang terus meningkat setiap tahun dan mencapai 100.000 ton pada tahun 2006 (Anonim, 2006). Ini menunjukkan bahwa pinang dapat menjadi komoditi yang sangat menjanjikan (Dinas Kehutanan, 2007). Mengingat prospek yang sangat cerah maka pinang perlu dibudidayakan secara intensif, selain untuk memenuhi permintaan pasar, juga dapat menjadikan sarana pelestarian sumber daya alam.

Untuk menunjang keberhasilan pengembangan pinang khususnya pembibitan, perlu adanya kegitan pemeliharaan yang memadai. Diperlukan adanya terobosan-terobosan baru yang lebih menguntungkan untuk mendukung pengembagan perkebunan pinang terutama perkebunan rakyat (Dewi, 2008) Menurut Siregar et al., (2000), petani selama ini dalam pembibitan pinang dan tanaman umur panjang lainnya biasanya tidak menggunakan zat pengatu tumbuh alami, padahal menurut Ardian dan Murniati, (2007) bibit merupakan produk dari suatu proses pengadaan bahan tanaman yang dapat berpengaruh terhadap pencapaian hasil produksi pada masa selanjutnya. Bahan tanaman yang berkualitas merupakan kebutuhan pokok suatu industri perkebunan. Selanjutnya menurut Jayusman (2005), kesehatan tanaman pada masa pembibitan akan mempengaruhi pertumbuhan dan tingginya produksi. Penyediaan bibit yang memiliki karakter unggul secara morfologi, fisiologis dan genetik akan sangat membantu keberhasilan tanaman di lapangan.

Salah satu cara untuk mendapatkan bibit pinang yang berkualitas adalah dengan penggunaan zat pengatur tumbuh alami. Berbagai bahan alami dapa digunakan sebagi substitusi ZPT diantaranya air kelapa dan urin sapi. Konsentrasi air kelapa yang umum digunakan dalam kultur jaringan adalah 2 15\% (Triagiano dan Denis, 2000), tetapi pada tanaman kentang kebutuhan air kelapa terbaik digunakan lebih banyak yaitu sampai 30\% (Nadapdap, 2000) Anty, (1987) dari penelitiannya melaporkan bahwa urin sapi mengandung zat perangsang tumbuh yang dapat digunakan sebagai pengatur tumbuh diantaranya adalah IAA.

Penggunaan air kelapa muda terbukti dari beberapa hasil penelitian yang telah dilakukan. Dalam penelitian Siahaan (2004) memperlihatkan bahwa penggunaan air kelapa muda sebagai ZPT dapat meningkatkan pertumbuhan dan produksi cabai merah. Penelitian lainnya menunjukkan produk hormon dari air kelapa ini mampu meningkatkan hasil kedelai hingga 64\%, kacang tanah hingga $15 \%$ dan sayuran hingga $20-30 \%$, serta dapat merangsang pembungaan pada anggrek seperti dendrobium dan phalaenopsis. Penelitian Ratnawati et al., (2013) menunjukkan bahwa perendaman benih kakao (Theobroma cacao, L.) dengan air kelapa muda berpengaruh terhadap tinggi bibit dan luas daun dimana perendaman selama 6 jam memberikan pertumbuhan bibit kakao terbaik.

Aplikasi urin sapi konsentrasi 20\% oleh Adijaya dan Sugiarta (2013) pada tanaman cabai dengan dosis 1,7 liter per tanaman dan frekuensi pemberian dua minggu sekali dapat meningkatkan pertumbuhan dan hasil tanaman.

Penggunaan bahan-bahan alami seperti air kelapa dan urin sapi baik sebagai ZPT atau sebagai pupuk dalam pembibitan pinang perlu diberikan sesuai dengan dosis, konsentrasi, lama perendaman maupun frekuensi pemberiannya, permasalahannya hal tersebut belum diketahui untuk pembibitan pinang sehingga perlu dilakukan penelitian tentang pengaruh lama perendaman dalam air kelapa dan frekuensi penyemprotan urin sapi terhadap pertumbuhan bibit pinang.

\section{Metode}

Penelitian dilaksanakan pada bulan Maret sampai Juni 2015 di Kelurahan Kefa Selatan, Kecamatan Kota Kefamenanu, Kabupaten TTU. Penelitian mengunakan Rancangan Acak Kelompok (RAK) faktorial 4 x 4 yang diulang tiga kali. Faktor pertama adalah lama perendaman dalam air kelapa $(\mathrm{P})$ yang terdiri dari empat aras yaitu tanpa perendaman $\left(\mathrm{p}_{0}\right), 3$ jam $\left(\mathrm{p}_{1}\right), 6$ jam $\left(\mathrm{p}_{2}\right)$ dan 9 jam $\left(\mathrm{p}_{3}\right)$. Faktor kedua adalah frekuensi penyemprotan urin sapi $(\mathrm{F})$ yang terdiri dari empat aras yaitu tanpa penyemprotan $\left(\mathrm{f}_{0}\right)$, satu kali $\left(\mathrm{f}_{1}\right)$, dua kali $\left(\mathrm{f}_{2}\right)$ dan tiga kali $\left(\mathrm{f}_{3}\right)$.

Air kelapa yang digunakan adalah air kelapa yang masih muda dengan konsentrasi $100 \%$ sebanyak 15 liter. Air kelapa ditampung dalam tiga wadah untuk perendaman benih masing-masing sebanyak 5 liter. Perendaman dilakukan dengan cara mencelupkan benih dalam air kelapa. Lama perendaman disesuaikan dengan perlakuan. Sebanyak 84 benih tidak direndam, sebanyak 84 benih direndam selama 3 jam, sebanyak 84 benih direndam selama 6 jam dan sebanyak 84 benih direndam selama 9 jam.

Urin sapi yang digunakan adalah urin sapi yang sudah di fermentasi dengan konsentrasi $20 \%$. Kebutuhan urin sapi selama penelitian adalah 171,36 liter yang dicampur merata dengan air sebanyak 685,44 liter. Frekuensi penyemprotan urin sapi dilakukan sesuai perlakuan dengan dosis 23,8 liter per petak yang dilakukan pada sore hari. Terdapat 12 petak percobaan yang tidak disemprot dengan urin sapi, terdapat 12 petak percobaan yang disemprot urin sapi satu minggu sekali dengan dosis 1,98 1/petak setiap kali penyemprotan (12 kali penyemprotan), terdapat 12 petak percobaan yang disemprot urin sapi dua minggu sekali dengan dosis 3,97 1/petak setiap kali penyemprotan (6 kali penyemprotan) dan terdapa 12 petak percobaan yang disemprot urin sapi tiga minggu sekali dengan dosis 5,95 1/petak setiap kali penyemprotan (4 kali penyemprotan). Penyemprotan menggunakan hand sprayer.

Data hasil pengamatan kemudian dianalisis dengan menggunakan sidik ragam (Anova) Rancangan Acak Kelompok (RAK). Rata-rata perlakuan selanjutnya diuji lanjut dengan menggunakan Duncan Multiple Range Test (DMRT) dengan tingkat signifikan 5\% sesuai petunjuk Gomez dan Gomez (1995). Analisis data menggunakan program SAS 9.1.

\section{Hasil dan Pembahasan}

\subsection{Tinggi Tanaman}

Hasil sidik ragam (Anova) menunjukkan bahwa interaksi antara lama perendaman air kelapa dan frekuensi penyemprotan urin sapi tidak berpengaruh secara nyata terhadap tinggi tanaman setiap waktu pengamatan.

Lama perendaman dalam air kelapa tidak berpengaruh nyata terhadap tinggi tanaman setiap waktu pengamatan tetapi data pada Tabel 1. menunjukkan bahwa saat 30 HST pinang yang sebelum ditanam benihnya direndam dalam air kelapa selama tiga jam cenderung lebih tinggi sedangkan saat 60 HST dan 90 HST pinang yang tidak direndam dalam air kelapa yang cenderung selalu lebih tinggi.

Frekuensi penyemprotan urin sapi berpengaruh nyata terhadap tinggi tanaman saat 30 HST dimana pinang yang tidak disemprot dengan urin sapi paling tinggi dan berbeda nyata dengan tinggi pinang yang disemprot dengan urin sapi dengan frekuensi tiga kali. Pada pengamatan selanjutnya, frekuensi penyemprotan urin sapi tidak berpengaruh nyata terhadap tinggi tanaman tetapi pinang yang tidak disemprot dengan urin sapi selalu cenderung lebih tinggi. 
Tabel 1. Tinggi Tanaman $(\mathrm{cm})$

\begin{tabular}{ccccccc}
\hline Waktu & Perendaman & \multicolumn{4}{c}{ Frekuensi Penyemprotan Urin Sapi } & \multirow{2}{*}{ Rerata } \\
\cline { 3 - 6 } Pengamatan & Air Kelapa & Kontrol & 1 Kali & 2 Kali & 3 Kali & \\
\hline \multirow{5}{*}{$30 \mathrm{HST}$} & Kontrol & $7,9 \mathrm{a}$ & $7,3 \mathrm{a}$ & $6,7 \mathrm{a}$ & $6,8 \mathrm{a}$ & $7,2 \mathrm{a}$ \\
& 3 Jam & $7,7 \mathrm{a}$ & $7,0 \mathrm{a}$ & $7,7 \mathrm{a}$ & $6,8 \mathrm{a}$ & $7,3 \mathrm{a}$ \\
& 6 Jam & $7,0 \mathrm{a}$ & $6,7 \mathrm{a}$ & $7,0 \mathrm{a}$ & $6,8 \mathrm{a}$ & $6,9 \mathrm{a}$ \\
& $9 \mathrm{Jam}$ & $7,5 \mathrm{a}$ & $6,9 \mathrm{a}$ & $6,4 \mathrm{a}$ & $6,0 \mathrm{a}$ & $6,7 \mathrm{a}$ \\
\cline { 2 - 6 } & Rerata & $7,5 \mathrm{a}$ & $7,0 \mathrm{a}$ & $7,0 \mathrm{ab}$ & $6,6 \mathrm{~b}$ & $(-)$ \\
\hline \multirow{5}{*}{$60 \mathrm{HST}$} & Kontrol & $8,9 \mathrm{a}$ & $8,8 \mathrm{a}$ & $8,5 \mathrm{a}$ & $8,4 \mathrm{a}$ & $8,7 \mathrm{a}$ \\
& 3 Jam & $8,9 \mathrm{a}$ & $8,9 \mathrm{a}$ & $8,6 \mathrm{a}$ & $8,2 \mathrm{a}$ & $8,6 \mathrm{a}$ \\
& 6 Jam & $8,8 \mathrm{a}$ & $8,7 \mathrm{a}$ & $8,6 \mathrm{a}$ & $8,3 \mathrm{a}$ & $8,6 \mathrm{a}$ \\
& $9 \mathrm{Jam}$ & $8,6 \mathrm{a}$ & $8,5 \mathrm{a}$ & $8,6 \mathrm{a}$ & $8,2 \mathrm{a}$ & $8,5 \mathrm{a}$ \\
\hline \multirow{5}{*}{$90 \mathrm{HST}$} & Rerata & $8,8 \mathrm{a}$ & $8,7 \mathrm{a}$ & $8,6 \mathrm{a}$ & $8,3 \mathrm{a}$ & $(-)$ \\
\hline & Kontrol & $9,9 \mathrm{a}$ & $9,7 \mathrm{a}$ & $9,6 \mathrm{a}$ & $9,6 \mathrm{a}$ & $9,7 \mathrm{a}$ \\
& 3 Jam & $9,7 \mathrm{a}$ & $9,6 \mathrm{a}$ & $9,5 \mathrm{a}$ & $9,4 \mathrm{a}$ & $9,5 \mathrm{a}$ \\
& 6 Jam & $9,7 \mathrm{a}$ & $9,5 \mathrm{a}$ & $9,4 \mathrm{a}$ & $9,3 \mathrm{a}$ & $9,5 \mathrm{a}$ \\
& 9 Jam & $9,7 \mathrm{a}$ & $9,7 \mathrm{a}$ & $9,6 \mathrm{a}$ & $9,5 \mathrm{a}$ & $9,6 \mathrm{a}$ \\
\hline & Rerata & $9,8 \mathrm{a}$ & $9,6 \mathrm{a}$ & $9,5 \mathrm{a}$ & $9,4 \mathrm{a}$ & $(-)$ \\
\hline
\end{tabular}

Keterangan: Angka yang diikuti dengan huruf yang sama pada kolom atau baris yang sama tidak berbeda nyata menurut uji DMRT @ 5\%.( - ) : Tidak terjadi interaksi antara faktor.

\subsection{Diameter Batang}

Hasil sidik ragam (Anova) menunjukkan bahwa interaksi antara lama perendaman air kelapa dan frekuensi penyemprotan urin sapi tidak berpengaruh secara nyata terhadap diameter batang setiap waktu pengamatan. Pengaruh tunggal masing-masing faktor juga tidak terjadi terhadap diameter batang setiap waktu pengamatan.

Data pada Tabel 2. menunjukkan bahwa batang bibit pinang yang sebelum ditanam benihnya direndam dalam air kelapa selama enam jam cenderung lebih besar saat pengamatan 30 HST dan 90 HST, sedangkan saat 60 HST batang bibit pinang yang sebelum ditanam benihnya direndam dalam air kelapa selama sembilan jam cenderung lebih besar. Batang pinang yang tidak disemprot dengan urin sapi cenderung lebih besar setiap kali pengamatan sedangkan batang pinang yang disemprot dengan urin sapi dengan frekuensi tiga kali selalu lebih kecil.

Tabel 2. Diameter Batang (mm)

\begin{tabular}{|c|c|c|c|c|c|c|}
\hline \multirow{2}{*}{$\begin{array}{c}\text { Waktu } \\
\text { Pengamatan }\end{array}$} & \multirow{2}{*}{$\begin{array}{c}\text { Perendaman } \\
\text { Air Kelapa }\end{array}$} & \multicolumn{4}{|c|}{ Frekuensi Penyemprotan Urin Sapi } & \multirow{2}{*}{ Rerata } \\
\hline & & Kontrol & 1 Kali & 2 Kali & 3 Kali & \\
\hline \multirow{5}{*}{$30 \mathrm{HST}$} & Kontrol & $5,8 \mathrm{a}$ & $5,6 \mathrm{a}$ & $5,3 \mathrm{a}$ & $5,0 \mathrm{a}$ & $5,4 \mathrm{a}$ \\
\hline & $3 \mathrm{Jam}$ & $5,7 \mathrm{a}$ & $5,6 \mathrm{a}$ & $5,5 \mathrm{a}$ & $5,2 \mathrm{a}$ & $5,5 \mathrm{a}$ \\
\hline & $6 \mathrm{Jam}$ & $5,7 \mathrm{a}$ & $5,9 \mathrm{a}$ & $5,8 \mathrm{a}$ & $5,7 \mathrm{a}$ & $5,8 \mathrm{a}$ \\
\hline & 9 Jam & $5,5 \mathrm{a}$ & $5,4 \mathrm{a}$ & $5,3 \mathrm{a}$ & $5,2 \mathrm{a}$ & $5,4 \mathrm{a}$ \\
\hline & Rerata & $5,6 \mathrm{a}$ & $5,5 \mathrm{a}$ & $5,4 \mathrm{a}$ & $5,3 \mathrm{a}$ & $(-)$ \\
\hline \multirow{5}{*}{$60 \mathrm{HST}$} & Kontrol & $6,5 \mathrm{a}$ & $6,5 \mathrm{a}$ & $6,3 \mathrm{a}$ & $6,2 \mathrm{a}$ & $6,4 \mathrm{a}$ \\
\hline & $3 \mathrm{Jam}$ & $6,6 \mathrm{a}$ & $6,5 \mathrm{a}$ & $6,4 \mathrm{a}$ & $6,2 \mathrm{a}$ & $6,4 \mathrm{a}$ \\
\hline & $6 \mathrm{Jam}$ & $6,6 \mathrm{a}$ & $6,6 \mathrm{a}$ & $6,2 \mathrm{a}$ & $6,2 \mathrm{a}$ & $6,4 \mathrm{a}$ \\
\hline & 9 Jam & $6,7 \mathrm{a}$ & $6,5 \mathrm{a}$ & $6,4 \mathrm{a}$ & $6,3 \mathrm{a}$ & $6,5 \mathrm{a}$ \\
\hline & Rerata & $6,6 \mathrm{a}$ & $6,5 \mathrm{a}$ & $6,3 \mathrm{a}$ & $6,2 \mathrm{a}$ & $(-)$ \\
\hline \multirow{5}{*}{$90 \mathrm{HST}$} & Kontrol & $7,6 \mathrm{a}$ & $7,4 \mathrm{a}$ & $7,4 \mathrm{a}$ & $7,2 \mathrm{a}$ & $7,4 \mathrm{a}$ \\
\hline & 3 Jam & $7,8 \mathrm{a}$ & 7,3 a & $7,2 \mathrm{a}$ & $7,1 \mathrm{a}$ & $7,4 \mathrm{a}$ \\
\hline & $6 \mathrm{Jam}$ & $7,7 \mathrm{a}$ & $7,6 \mathrm{a}$ & $7,3 \mathrm{a}$ & $7,2 \mathrm{a}$ & $7,5 \mathrm{a}$ \\
\hline & 9 Jam & $7,5 \mathrm{a}$ & $7,4 \mathrm{a}$ & $7,3 \mathrm{a}$ & $7,2 \mathrm{a}$ & $7,4 \mathrm{a}$ \\
\hline & Rerata & $7,7 \mathrm{a}$ & $7,4 \mathrm{a}$ & $7,3 \mathrm{a}$ & $7,2 \mathrm{a}$ & $(-)$ \\
\hline
\end{tabular}

Keterangan: Angka yang diikuti dengan huruf yang sama pada kolom atau baris yang sama tidak berbeda nyata menurut uji DMRT @ 5\%. ( - ) : Tidak terjadi interaksi antara faktor.

\subsection{Luas Daun}

Hasil sidik ragam (Anova) menunjukkan bahwa interaksi antara lama perendaman air kelapa dan frekuensi penyemprotan urin sapi tidak berpengaruh secara nyata terhadap luas daun, demikian juga pengaruh tunggal masing-masing faktor tidak terjadi terhadap luas daun.

Data pada Tabel 3. menunjukkan bahwa permukaan daun bibit pinang yang sebelum ditanam benihnya direndam dalam air kelapa selama enam jam lebih luas sedangkan permukaan daun bibit pinang yang sebelum ditanam benihnya direndam dalam air kelapa selama tiga jam paling sempit. Permukaan daun pinang yang tidak disemprot dengan urin sapi cenderung lebih luas sedangkan permukaan daun pinang yang disemprot dengan urin sapi dengan frekuensi dua kali paling sempit.

Tabel 3. Luas Daun $\left(\mathrm{cm}^{2}\right)$

\begin{tabular}{cccccc}
\hline Lama Perendaman & \multicolumn{4}{c}{ Frekuensi Penyemprotan Urin Sapi } & \multirow{2}{*}{ Rerata } \\
\cline { 2 - 5 } Dalam Air Kelapa & Kontrol & 1 Kali & 2 Kali & 3 Kali & \\
\hline Kontrol & $180,8 \mathrm{a}$ & $241,2 \mathrm{a}$ & $242,0 \mathrm{a}$ & $211,5 \mathrm{a}$ & $218,9 \mathrm{a}$ \\
3 Jam & $211,5 \mathrm{a}$ & $199,0 \mathrm{a}$ & $198,0 \mathrm{a}$ & $202,5 \mathrm{a}$ & $202,8 \mathrm{a}$ \\
6 Jam & $262,8 \mathrm{a}$ & $210,3 \mathrm{a}$ & $228,8 \mathrm{a}$ & $235,5 \mathrm{a}$ & $234,4 \mathrm{a}$ \\
9 Jam & $235,8 \mathrm{a}$ & $229,2 \mathrm{a}$ & $171,3 \mathrm{a}$ & $220,5 \mathrm{a}$ & $214,2 \mathrm{a}$ \\
\hline Rerata & 222,8 a & $219,9 \mathrm{a}$ & $210,0 \mathrm{a}$ & $217,5 \mathrm{a}$ & $(-$ ) \\
\hline Keterangan: & Angka yang diikuti dengan huruf yang sama pada kolom atau baris yang \\
& sama tidak berbeda nyata menurut uji DMRT @ 5\%. (- ) : Tidak terjadi \\
& interaksi antara faktor.
\end{tabular}

\subsection{Panjang Akar}

Hasil sidik ragam (Anova) menunjukkan bahwa interaksi antara lama perendaman air kelapa dan frekuensi penyemprotan urin sapi tidak berpengaruh secara nyata terhadap panjang akar, demikian juga pengaruh tunggal masingmasing faktor tidak terjadi terhadap panjang akar.

Data pada Tabel 4. menunjukkan bahwa akar pinang yang tidak direndam dalam air kelapa dan akar pinang yang sebelum ditanam benihnya direndam dalam air kelapa selama tiga jam dan enam jam lebih panjang dibandingkan akar pinang yang sebelum ditanam benihnya direndam dalam air kelapa selama sembilan jam. Akar pinang yang disemprot dengan urin sapi dengan frekuensi tiga kali cenderung lebih panjang sedangkan akar pinang yang disemprot dengan urin sapi dengan frekuensi satu kali paling pendek.

\section{Tabel 4. Panjang Akar $(\mathrm{cm})$}

\begin{tabular}{cccccc}
\hline Lama Perendaman & \multicolumn{3}{c}{ Frekuensi Penyemprotan Urin Sapi } & \multirow{2}{*}{ Rerata } \\
\cline { 2 - 5 } Dalam Air Kelapa & Kontrol & 1 Kali & 2 Kali & 3 Kali & \\
\hline Kontrol & $14,7 \mathrm{a}$ & $16,4 \mathrm{a}$ & $16,4 \mathrm{a}$ & $16,6 \mathrm{a}$ & $16,0 \mathrm{a}$ \\
3 Jam & $16,7 \mathrm{a}$ & $15,2 \mathrm{a}$ & $15,2 \mathrm{a}$ & $17,0 \mathrm{a}$ & $16,0 \mathrm{a}$ \\
6 Jam & $16,0 \mathrm{a}$ & $14,8 \mathrm{a}$ & $16,6 \mathrm{a}$ & $16,7 \mathrm{a}$ & $16,0 \mathrm{a}$ \\
9 Jam & $14,6 \mathrm{a}$ & $14,6 \mathrm{a}$ & $15,3 \mathrm{a}$ & $15,8 \mathrm{a}$ & $15,1 \mathrm{a}$ \\
\hline Rerata & $15,5 \mathrm{a}$ & $15,2 \mathrm{a}$ & $15,9 \mathrm{a}$ & $16,5 \mathrm{a}$ & $(-)$ \\
\hline Keterangan: & Angka yang diikuti dengan huruf yang sama pada kolom atau baris yang \\
& sama tidak berbeda nyata menurut uji DMRT @ 5\%. (-) : Tidak terjadi \\
& interaksi antara faktor.
\end{tabular}

\subsection{Berat Segar Bibit}

Hasil sidik ragam (Anova) menunjukkan bahwa interaksi antara lama perendaman air kelapa dan frekuensi penyemprotan urin sapi tidak berpengaruh secara nyata terhadap berat segar bibit, demikian juga pengaruh tunggal masingmasing faktor tidak terjadi terhadap berat segar bibit.

Data pada Tabel 5. menunjukkan bahwa berat segar bibit pinang yang tidak direndam dalam air kelapa dan pinang yang sebelum ditanam benihnya direndam dalam air kelapa selama enam jam cenderung lebih berat dibandingkan berat segar bibit pinang yang sebelum ditanam benihnya direndam dalam air kelapa selama tiga jam dan sembilan jam. Berat segar bibit pinang yang tidak disemprot dengan urin sapi cenderung lebih berat sedangkan berat segar pinang yang disemprot dengan urin sapi lebih ringan.

\begin{tabular}{cccccc}
\multicolumn{7}{l}{ Tabel 5. Berat Segar Bibit (g) } \\
\hline Lama Perendaman & \multicolumn{4}{l}{ Frekuensi Penyemprotan Urin Sapi } & \multirow{2}{*}{ Rerata } \\
\cline { 2 - 5 } Dalam Air Kelapa & Kontrol & 1 Kali & 2 Kali & 3 Kali & \\
\hline Kontrol & $4,6 \mathrm{a}$ & $4,3 \mathrm{a}$ & $3,8 \mathrm{a}$ & $4,5 \mathrm{a}$ & $4,3 \mathrm{a}$ \\
3 Jam & $4,2 \mathrm{a}$ & $4,0 \mathrm{a}$ & $4,0 \mathrm{a}$ & $4,0 \mathrm{a}$ & $4,1 \mathrm{a}$ \\
6 Jam & $4,4 \mathrm{a}$ & $4,1 \mathrm{a}$ & $4,5 \mathrm{a}$ & $4,2 \mathrm{a}$ & $4,3 \mathrm{a}$ \\
9 Jam & $4,1 \mathrm{a}$ & $4,1 \mathrm{a}$ & $4,3 \mathrm{a}$ & $3,8 \mathrm{a}$ & $4,1 \mathrm{a}$ \\
\hline Rerata & $4,3 \mathrm{a}$ & $4,1 \mathrm{a}$ & $4,1 \mathrm{a}$ & $4,1 \mathrm{a}$ & $(-)$ \\
\hline Keterangan: & Angka yang diikuti dengan huruf yang sama pada kolom atau baris yang \\
& sama tidak berbeda nyata menurut uji DMRT @ 5\%. (-) : Tidak terjadi \\
& interaksi antara faktor.
\end{tabular}

\subsection{Berat Kering Bibit}

Hasil sidik ragam (Anova) menunjukkan bahwa interaksi antara lama perendaman air kelapa dan frekuensi penyemprotan urin sapi tidak berpengaruh secara nyata terhadap berat kering bibit, demikian juga pengaruh tunggal masingmasing faktor tidak terjadi terhadap berat kering bibit. Bahan kering bibit yang dihasilkan dengan pemberian perlakuan lama perendaman dalam air kelapa maupun frekuensi penyemprotan urin sapi memiliki berat yang sama pada setiap level perlakuan yang diberikan.

Tabel 6. Berat Kering Bibit (g)

\begin{tabular}{cccccc}
\hline Lama Perendaman & \multicolumn{3}{c}{ Frekuensi Penyemprotan Urin Sapi } & \multirow{2}{*}{ Rerata } \\
\cline { 2 - 5 } Dalam Air Kelapa & Kontrol & 1 Kali & 2 Kali & 3 Kali & \\
\hline Kontrol & $0,9 \mathrm{a}$ & $0,8 \mathrm{a}$ & $0,7 \mathrm{a}$ & $0,9 \mathrm{a}$ & $0,8 \mathrm{a}$ \\
3 Jam & $0,8 \mathrm{a}$ & $0,8 \mathrm{a}$ & $0,8 \mathrm{a}$ & $0,8 \mathrm{a}$ & $0,8 \mathrm{a}$ \\
6 Jam & $0,7 \mathrm{a}$ & $0,8 \mathrm{a}$ & $0,9 \mathrm{a}$ & $0,8 \mathrm{a}$ & $0,8 \mathrm{a}$ \\
9 Jam & $0,7 \mathrm{a}$ & $0,9 \mathrm{a}$ & $0,8 \mathrm{a}$ & $0,7 \mathrm{a}$ & $0,8 \mathrm{a}$ \\
\hline Rerata & $0,8 \mathrm{a}$ & $0,8 \mathrm{a}$ & $0,8 \mathrm{a}$ & $0,8 \mathrm{a}$ & $(-)$ \\
\hline Keterangan: & Angka yang diikuti dengan huruf yang sama pada kolom atau baris yang \\
& sama tidak berbeda nyata menurut uji DMRT @ 5\%. (-) : Tidak terjadi \\
& interaksi antara faktor.
\end{tabular}

\subsection{Pembahasan}

Secara umum dapat dinyatakan bahwa lama perendaman air kelapa dan frekuensi penyemprotan urin sapi tidak memberikan pengaruh interaksi maupun pengaruh utama terhadap pertumbuhan bibit pinang. Pinang yang tidak direndam dalam air kelapa memiliki ukuran yang lebih tinggi dibanding pinang yang direndam dalam air kelapa meskipun batangnya berukuran lebih kecil dengan permukaan daun yang lebih sempit.

Demikian juga dengan pinang yang tidak disemprot dengan urin sapi memiliki pertumbuhan yang lebih baik berupa bibit yang lebih tinggi, batang yang lebih besar, daun yang lebih luas dan bibit segar yang lebih berat. 


\section{Simpulan}

Tidak terjadi pengaruh interaksi antara lama perendaman dan frekuensi penyemprotan pada semua parameter. Lama perendaman dalam air kelapa tidak berpengaruh nyata pada semua parameter sedangkan frekuensi penyemprotan urin sapi juga hanya berpengaruh nyata terhadap tinggi tanaman $30 \mathrm{HST}$. Perendaman dalam air kelapa selama enam jam lebih baik bagi pertumbuhan bibit pinang, sedangkan penyemprotan urin sapi memberikan dampak negatif terhadap pertumbuhan bibit pinang.

\section{Pustaka}

Adijaya dan Sugiarta (2013) Pengaruh Macam Pupuk Organik Cair dan Konsentrasi IAA terhadap Pertumbuhan Stek Tanaman Stevia (Stev Aiarebaudiana Bertoni M.), Fakultas Pertanian, Universitas Negeri Surakarta. (Skripsi)

Anonim. 2006. Indonesia Tetap Jadi Produsen Pinang Tebesar. [Internet]. [Diunduh 2006 september 10)]. Tersedia pada www. Pemerintah sumatra utara. Htm.

Anty K. 1987. Pengaruh Urine Sapi Terhadap Pertumbuhan dan Hasil Jagung Manis. Politeknik Pertanian Andalas.

Ardian dan Murniati, 2007 Pemanfaatan Urine Sapi Pada Setek Batang Tanaman Jarak Pagar (Jatropha curcas L). Jurnal Saint dan Teknologi. UNRI. Vol. 6. No. 2: 1-8

Dewi R I. 2008. Peranan dan Fungsi Fitohormon bagi Pertumbuhan Tanaman. Universitas Padjajaran. Bandung.

Dinas Kehutanan . 2007. Laporan Tahunan. Dinas Kehutanan Provinsi Nanggroe Aceh Darussalam.

Gomez. KA dan Gomez AA. 1995. Statistical Procedures for Agricultural Research. John Wiley and Sons.

Jayusman. 2005. Perbanyakan stek pada teknik penyiapan bahanklonal Gmelina, Jurnal Penelitian Hutan Tanaman, 2 (3):103-105.ch. John Wiley and Sons.

Lutony T L. 1992. Pinang Sirih, Komoditi Ekspor dan Serbaguna. Kanisius. Yogyakarta.

Nadapdap, C. 2000. Penggunaan pupuk komersial dan air kelapa sebagai media perbanyakan in vitro Tanaman Kentang (solanum tuberrosum L). [Skripsi].

Ratnawati, Saputra I. S, dan Yoseva, 2013. Waktu Perendaman Benih Dengan Air Kelapa Muda Terhadap Pertumbuhan Bibit Kakao (Theobroma cacao, L) [Skripsi]. Riau : Fakultas Pertanian, Universitas Riau.

Siahaan, E. 2004. Pengaruh Kosentrasi Air Kelapa Muda Terhadap Pertumbuhan Produksi Cabai Merah (Capsicum annum L.). [Skripsi]. Fakultas Pertanian. Universitas Riau.

Siregar T H S, Riyadi L. Nuraeni. 2000. Budidaya pengolahan dan pemasaran cokelat. Cetakan XI.

Trigiano R N dan Denis J G. 2000. Plant Tissue Culture Concept and Laboratory Exercises Second Ed. CRC Press. Washington DC. 27p. 